\title{
IN DEFENCE OF THEORY AND THE PATIENCE OF THINGS
}

\section{Brit Solli}

\begin{abstract}
Las Cosas
El bastón, las monedas, el llavero ... Cuántas cosas, limas, umbrales, atlas, copas, clavos, nos sirven como tácitos esclavos, ciegas y extrañamente sigilosas! Durarán más allá de nuestro olvido; no sabrán nunca que nos hemos ido (Jorge Luis Borges I983:43).
\end{abstract}

\section{Tingene}

Spaserstokken, myntene, nøkkelknippet.... Så mange ting, filer, dørterskler, nakkevirvler, drikkebegre, nagler, de tjener oss som tause slaver, blinde og usedvanlig hemmelighetsfulle! De vil vare hinsides vår glemsel; de vil aldri vite at vi er borte (my translation into Norwegian).

\section{Things}

My walking-stick, small change, key-ring... Many things, files, sills, atlases, wine-glasses, nails, which serve us, like unspeaking slaves, so blind and so mysteriously secret! They'll long outlast our oblivion; and never know that we are gone (translation A.S. Kline, 2008).

First and foremost; I have truly enjoyed reading Bjørnar Olsen's personal passage through "a disciplinary landscape of the recent past" and his proposed four trends for the future. When the editors of Current Swedish Archaeology for the journal's twentieth anniversary invite established university archaeologists well over the age of fifty to comment on the recent past and trends for the future, a taste of individual experiences is 
hard to avoid. Like Olsen, I realize that my comment may show a dint of "intellectual narcissism".

Cultural events in Norway in the last decade seem indeed to be based on "anniversaries": The 2005 jubilee marking the dissolution of the union with Sweden on 7 June 1905; in 2006 the writer Henrik Ibsen (I828I906) was celebrated; in 2010 it was Bjørnstjerne Bjørnson's (I832I9I0) year of commemoration; the Nobel laureate of I920, Knut Hamsun (I859-I952), was not so much celebrated in 2009. He sided with the Nazis during the German occupation of Norway in the long years I940-I945. And now we are in for another grand anniversary in 20I4, celebrating the Norwegian Constitution of I7 May I8I4, when Norway said farewell to 400 years of union with Denmark.

The year 1905 was also an important one for archaeology in Norway; the parliament passed the first Cultural Heritage Act (Lov om Fredning og Bevaring af Fortidslevninger, I3 July 1905). Through this law archaeological sites and monuments were protected and considered to be the property and heritage of the nation and not of individual landowners. Norwegian archaeology a hundred years ago was firmly grounded in the Scandinavian tradition of Oscar Montelius (e.g. I885) and Sophus Müller (e.g. I884). Archaeology was considered to be a cross-disciplinary field from the first kitchen-midden commission in I848 onwards, and "what we now term 'ecological' perspectives were developed methodologically, and 'ecofacts' were studied both by natural scientists and archaeologists" (see Solli 201 I:49-50 for references). Graham Clark knew the Scandinavian research tradition well, and in the preface to his book The Mesolithic Settlement of Northern Europe (1936) the acknowledgements demonstrate that Clark's eco-archaeological perspectives, further developed in the Star Carr investigations (Clark I954), came from Scandinavia. The eco-archaeology presented by Lewis Binford and others in the I960s were not new to Scandinavian archaeology, but the anthropological and system-theoretical framework were unfamiliar. The New Archaeology's (NA) insistence that archaeology should be classified as a Science following strict positivist hypothetical-deductive methods, with the goal of reaching scientific explanations with the ability to predict past human behaviour, were also of a kind and jargon different from the traditional Scandinavian eco-archaeology which aimed at writing the cultural history of the nation.

Binford's Archaeology as Anthropology (1962) certainly had an impact on Scandinavian archaeology but, in my opinion, before 1970 the impact was marginal. When Scandinavian archaeology students started to gather at the so-called "Kontaktseminar" the winds from the west augmented from a little breeze to a storm at some of the Scandinavian 
archaeology departments, but as Olsen points out: "Operating in this entrenched archaeological landscape was not without risks." I consider that the trenches, constructed in defence against the invasion of both NA and postprocessual archaeology, turned out to be deeper in Denmark than elsewhere in Scandinavia, and this led to an exodus of talented archaeologists from Denmark.

Several of the younger generation of archaeologists all over Scandinavia were inspired by the positivist New Archaeology, and paradoxically also, in the vein of the times, Marxist theories (Solli I992:I0I). When I started to study archaeology at the University of Bergen in autumn 1979, I quite soon became an enthusiastic fan of the New Archaeology and System Theory, and Binford eventually became a veritable hero of mine!

\section{BACK TO THE EIGHTIES - WHAT HAPPENED IN OSLO?}

In the autumn of 1983 , after having studied Spanish and History, I began to read archaeology again at the University of Oslo under the supervision of Stig Welinder. I clearly remember a seminar, not very well attended by the magister students, where the 1982 volumes Symbolic and Structural Archaeology (Hodder 1982a) and Symbols in Action (1982b) were up for discussion. What was this? A return to descriptive particularism? Archaeology as History - or even worse - as Art? Empathetic understanding? An ideational concept of culture? A return to Childe's concept of culture? I was flabbergasted, but also determined to find out more about this "reactionary" cultural and contextual archaeology "that sees archaeology as an historical discipline" (Hodder 1982a:I3).

Early in my studies I had stumbled over a piece of advice given by Karl Popper to young researchers: "Try to learn what people are discussing nowadays in Science. Find out where difficulties arise, and take an interest in disagreement. These are the questions you should take up" (Popper I963:I29). Now, over 30 years later, I still think it is good advice to live by. So back in 1983 I decided, after the first shock, to find out what the "coggies" were up to.

During the I980s in Oslo we were about ten active magister students (not to be confused with today's master's students). Stig Welinder, and from the autumn semester 1985 also Bjørn Myhre, did their best to organize theory seminars, but it would be a lie to say that the discussions were vibrant. However, the "Universitetets Oldsaksamling", of which the teaching department was a part, had a very good library to explore. And both Stig and Bjørn encouraged us to participate in conferences 
both at home and abroad, e.g. the first Nordic Tag in Helsingør in 1985 (a disappointment, not much explicit theory there) and the British Tag in London in I986. We heard rumours that things were going on in Tromsø. Ian Hodder visited Oslo in autumn 1987, and as far as I remember the seminar room was not at all "packed".

For most students and established archaeologists in Oslo during the I980s it was archaeology as cultural history, and especially so among those doing Iron Age and medieval archaeology. A few of the established archaeologists working with earlier periods were somewhat inspired by the New Archaeology. The atmosphere cannot be described as open and innovative. If I came up with postprocessually inspired ideas the probability was high that some veteran over lunch told me that A. W. Brøgger had written something similar before World War II. Which of course was not true; Brøgger did not write postprocessual archaeology. Writing a magister artium thesis (Solli I989a) and later a doctor artium dissertation (Solli I996) working on Viking Age and medieval material, and being inspired by the postprocessual debates of the I980s and early I990s, was not exactly the safest track to tenure.

Although I never experienced the "fierce debates ... waged at the packed research seminars in Downing Street", Cambridge, I think that the heat of the debates during the 1980 o was, even at a distance from the academic metropolises, a fun read, and writing in 1993 (published in I996) I expressed my enthusiasm, somewhat tongue-in-cheek, this way:

Never have so many French and German thinkers quite un-problematically co-habited on fewer pages. I refuse to call this eclectic; it was just a time of euphoria:

- Finally, archaeology is going to play along with disciplines such as philosophy, the history of ideas, and anthropology! Finally, we shall be part of the general ongoing cultural critique! And look! We have read them all, from Bakhtin to Derrida, and from Kristeva via Gadamer to Lévi-Strauss. Not to forget Roland Barthes and Michel Foucault. And we are now competent enough to comment on these great thinkers; we can use them in archaeology! (Solli 1996:19).

But now I have been rambling on about my own experiences, let's get back to Olsen's article.

\section{WHAT'S THE USE OF THEORY?}

Bjørnar Olsen is right in pointing out that, from around 2000, theoretical debates in archaeology were "taught rather than fought". The 
publishing industry found a curriculum market and started to produce handbooks, readers and textbooks offering the students various theoretical positions written by the proper academics from the right institutions to sum up the state of the art in the world of Anglo-American-influenced archaeology. The euphoria of the I980s is now a faint memory.

Olsen asks what should count as theoretical archaeology. He does not really answer this question, and throughout the article it is not quite clear what he means by theory; his aim seems to be, as he puts it, to "stop thinking that theory always intervenes and is indispensable to understanding", we should "instead admit that the things themselves have a say and sometimes a very substantial one, for how meaning is arrived at" (cf. Olsen 20I0; Edgeworth 20I2).

It would certainly have been easier to follow Olsen's line of reasoning if he had explained to us what he means by theory. He critically implies that theory often is seen as "the head and practice is the obedient acting body". Such a view of theory is static and rather unproductive, so I suppose Olsen and I agree that "top-down" applications of theory may lead to conservative results, i.e. that archaeological material illustrates the theory. The way forward is to insist on a "from the ground-up" understanding where the "things" challenge the theoretical assumptions and maybe sometimes alter the theory altogether.

However, for me theory has never been the "head", something aloft and abstract from practice; theory has to do with certain principles, ways of seeing the world. ${ }^{\mathrm{I}}$ New theoretical perspectives can open up new territories and produce ideas about other possible interpretations of both old finds and new discoveries. A theory may also be of firmer kind and constitute a general system of explicit, well-founded assumptions that can explain how observations and facts are interdependent. Below follows an analysis of an antiquarian observation without archaeological theory.

1 Predefined ideas about what we are going to observe, simply theory, helps us to interpret what we "see" and "observe". The word/term "theory" has Greek roots: Theaomai - to watch, stare with some amazement/ wondering.

Theoreo - to watch, look at, look over, inspect, contemplate, think about, and even to consult an oracle.

Theorema - an object of contemplation, and "subject of investigation".

Theoros - A spectator/ a person present at the theatre or at athletic games, i.e. sports. "The witness to sacred festivals (and a source of the later philosophic notion of theoria" (Richard J. Bernstein 1983:123).

Theatron - a place where one gathers to watch, see something.

Theoria - a mission to an oracle, contemplation and consideration. 


\section{HOW TO DISCOVER THE EXISTENCE OF CULTURAL LAYERS}

Every archaeologist knows what he/she sees when uncovering cultural layers. It is just there, can't be missed. Who needs theory to interpret a cultural layer on an archaeological site? Cultural layers may contain remains of fire places, cracked stones, garbage, constructions, rather messy things, surely no theory should be necessary to understand that this messiness of things are the remains of human activity? The answer to this question is not at all straightforward. To illustrate this I shall again turn to the archaeological site that I know best; the small town on the island of Veøy in Romsdal.

In 1768 the parson Hans Peter Schnitler wrote about the remarkable soil conditions on Veøy: Schnitler observed that on the island of Veøy the soil is very black, deep and fat. He thinks that this soil is constituted by rotting wood, rotting organic material, firewood stemming from the old Kaupstadir (small town) He adds that even remains of animals and human bodies and manure have contributed to this fat soil, so different from the known soil conditions on the mainland.

Of course we now know what Schnitler described, namely archaeological cultural layers. Veøy was visited by many antiquarians throughout the eighteenth and nineteenth centuries but not one made the same point as Schnitler, although the peculiar black and fat soil conditions on Veøy were well known in the region of Romsdal. Not until I953, when the archaeologist Asbjørn Herteig (I954) conducted a small excavation on the island, was the black soil of Veøy interpreted as cultural layers with explicit reference to similar conditions in Hedeby (Die Schwartze Erde) and the Black Earth (Svarta Jorden) in Birka.

Why was this - for us now obvious - fact not stated earlier? Schnitler wrote in a pre-archaeological period; archaeology did not exist as an academic discipline in the eighteenth century (Svestad I995). Antiquarianism yes, archaeology no. Schnitler's observations occurred outside the much later archaeological discourse, the observations did not belong inside a disciplinary discourse (Foucault I972), [or space/field (Bourdieu I977), paradigm (Kuhn I962), vocabulary (Rorty I989)], and they were understood by Schnitler's contemporaries. In fact, almost 200 years passed before the black soils of Veøy, which had been observed and remarked upon by many antiquarians and historians of the island for 200 years, were placed inside the archaeological discourse and labelled “cultural layers". Schnitler's statement was outside any archaeological discourse, and as a non-discursive statement it was not comprehensible to his contemporaries. 
The predicament and awkward question is: If we need predefined ideas/theories to discover and understand new things, do we really ever discover new things? I do not think that this question has a definite answer; we discover new things and new archaeological find categories all the time. Yet such discoveries do not fall out of the blue skies, but are related to a certain discourse, field, vocabulary, in the Sciences a paradigm, and to previous discoveries.

What do I mean by discourse? A discourse can be defined as all kinds of authoritative statements, not only speech and text; for example Oscar Montelius' famous drawings of the typological development of the stagecoach into a car are discursive statements.

Michel Foucault's (1972) concept of discourse constitutes a building block in his "archaeology of knowledge" construction. And Foucault talks about discursive formations; formations guided by rules that encircle certain objects and problems that are transformed into discursive practices. What happens in the nineteenth century is that archaeology is established as a discursive practice. During Schnitler's time in the eighteenth century, archaeology was not established as a discursive formation or practice.

The existence of archaeological artefacts and structures which are so obvious that we don't even reflect upon their existence as such has a research history. Phenomena that we now observe but do not classify as archaeological may well turn out to be of the utmost archaeological significance in the future and be written into the archaeological discourse.

The breaking point of theory is that it opens your mind up; theories produce ideas that can be developed in a comparative context with hitherto unknown phenomena; theories can make you see the world with new eyes. The black soil of Veøy was interpreted correctly by Schnitler, for him the things themselves had a say, but for others the things had another say inside the discourse of agriculture not archaeology. This is because archaeology as a discipline was not yet established and the theoretical principles of archaeology were not known to Schnitler either. The things did speak for themselves, but the correct (!) interpretation required a theoretical context that was not yet invented. This is why theory intervenes and helps understanding.

However, old theories fiercely defended by a stubborn establishment may impede new discoveries and interpretations - especially the kind of theories which are implicit and under-communicated. David Clarke in his seminal paper "Archaeology: The Loss of Innocence", quoted the economist John Maynard Keynes who once said that "practical men who believe themselves to be quite exempt from any intellectual influences are ... usually the unwitting slaves of some defunct theorist" (Clarke 
1973:7). Olsen has not convinced me that a return to things makes theory more dispensable, and I still think that Keynes has a good point.

\section{A NEW GEOGRAPHY?}

Olsen proposes as his first trend that we in the future will see "a new geography" more dispersed than in the I980s; "a less metropolized archaeological landscape". He is right that new networks of collaborating archaeologists are now assembled through the Internet, and that the influence of the universities that was important in the I980s has faded dramatically. But I think Olsen is too optimistic about the waning of the academic metropolises. Influential theoretical archaeological journals, e.g. Archaeological Dialogues (Cambridge University Press) and Journal of Material Culture (Sage, London), are issued by major publishing companies situated in academic metropolises, and consequently profiting from the academic networks existing there. The gravity of the Ivy League universities in the US is a major force and will be in the foreseeable future. Bjørnar Olsen himself has spent sabbatical years at Stanford, not at the University of Oulu. In Defense of Things was, according to the acknowledgements in the afterword, influenced by the intellectual environment at Stanford and partly written there, not in Stockholm. Olsen remarks that the SSA (Hodder I982a) was a "perfectly timed statement rather than the substance of what was said", and I would add it was a seminar report in English published at the Cambridge University Press, not in Stensilserie B at the University of Tromsø.

In spite of Asia's rising economic and cultural force, there is reason to believe that English for a long time in the future will be the lingua franca of academic disciplines. Although network building is facilitated by the Internet, I am quite certain that being associated with the academic metropolises will be an advantage in the future too. So, if Scandinavian Universities wish to compete in the game of international publishing, both young talents and established researchers should be granted sabbatical years and means to visit the academic metropolises of the world. Brilliant books like In Defense of Things may be written!

\section{A TURN TO THINGS THEMSELVES?}

According to Olsen, the time for our discipline is NOW; "the current situation actually constitutes a rare archaeological moment". In both Humanities and Social Sciences the linguistic and humanist dominant 
discourse of the last forty years is challenged by new materialist and post-human perspectives challenging the anthropocentric understanding of nearly everything in the humanities and social sciences; the relationship between humans and things, culture and nature must be scrutinized from wider theoretical (!) perspectives giving matter, animals and things a say. And since archaeology is par excellence the discipline of things, Olsen encourages us to seize the moment. He maintains that this new interest in things does not go deep enough; the things in focus are often monumental or spectacular either in size or technology. Considering technology, I think about things like Artificial Intelligence, nano-medicine, body implants, robots etc. Olsen contests the humanization of things; the moment that is up for grabs is to recognize things as things and describe them as things in themselves.

As other archaeologists have done before him, Olsen shuns any idealistic interpretation of matter and things:

We do not find "fossilised" ideas, we find the arrangements of material which derive from the operation of a system of adaptation culturally integrated at some level. I don't have to know how the participants thought about the system to investigate it as a system of adaptation in a knowable natural world (Binford 1982:162).

Olsen proclaims in his conclusion that "a release from the humanist imperative that humans are a fundamental ingredient in every relation of interest, which also will spark off a new and more diverse interest in ecological approaches in archaeology". He emphasizes that a return to things does not mean that things be turned into text, or "extrasomatic means of adaptations". However, I wonder if Olsen's defence of things isn't also a return to a kind of Binfordian eco-materialism?

As far as I understand Olsen, the main focus should not be on "the Indian behind the artifact" or "the System behind the artifact" but the assemblages of things themselves in all their messiness. He suggests that the messiness of "smashed pots, slag lumps, flint debris, caulking resins, burnt bones, fire-cracked rocks" etc. resist "humanizing and interpretative exploitation".

In medieval urban archaeology, material gatherings like this have a name: mass material. According to Olsen, "their assembly, gathering and bonding resist temporal ordering and chronological sequencing". This statement reminds me of a discussion in Scandinavian medieval archaeology in the late 1980 os and early 1990 on on the value of mass material in medieval archaeology. Anders Andrén (1985) suggested that the manifest remains such as consciously constructed monuments are primordial and create an interpretative framework inside of which the 
randomly agglomerated latent mass material is secondary. The massmaterial constitutes "cultural sludge filled with all kinds of rubbish and remains of human activity" (Andrén I985:I0, my translation). Andrén's classification of mass material as latent and secondary was met with resistance (Nordeide r989a and b, Solli r989b)

It is certainly difficult to order mass material chronologically in the shape of messy remains from ordinary daily life; this material may "resist naming and classification", but it is not impossible (Solli I989a and b). The stratigraphic analysis of deep cultural layers is based on finding order in that which appears disorderly, e.g. by using the Harris matrix as a tool. Olsen seems to mean that we should stop doing this and "end our current obsession with turning mute things into storytellers". However, in my opinion these mute and patient things are full of stories of e.g. garbage disposal; matter out of - and in - place etc. These enduring gatherings of things are quite fit to carry "interpretative burdens", and by studying formation processes assemblages of things can "produce alternative histories". But without chronology, taphonomic analysis, and sequencing these histories will be "thin" (cf. Geertz I973) surface-like histories of messy matter, and how interesting is that?

To understand such assemblages it is important to make sequences, underpinning chronology and classification. I see no reason why these no-things should resist naming and classification. To write is to name; how are we going describe assemblages of things without naming and classifying?

\section{A FAREWELL TO INTERPRETATION?}

Perhaps the trademark of postprocessualism was abstract interpretations cut off from the very subsistence-economic everyday life and struggle to survive in the past. Olsen's examples are quite amusing and I agree: a river is not always cosmic; a rock art depiction of a tree is not always the world-tree; a boat is useful as a floating and transport device for humans, namely as a boat; daily chores were not trivial and comprised knowledge now long forgotten. Archaeology can rediscover old tacit skills without the theoretical umbrellas of structuralism or poststructuralism. I concur with Olsen "that things may be the source of their own signification". Things have special "affordances" (cf. Gibson I986:I38-I39), but a boat can be used as something else than a floating device; upside down it can be used as a shelter, a big boat can be turned into a boat-house for smaller boats. The boatness of the boat contains many un-boatly affordances. I guess that Olsen would classify this as 
not over-interpretation of the boat possibilities, but as sensible "everyday and real" handling of the original boat.

I side with Olsen's statement that "such engagements with things, animals and other natures are far from trivial, in the derogatory sense of the word, but imply knowledge, care and attachment, and a respect for what things are in their own being." Maybe the turn to things should also involve a renewal of experimental archaeology? Archaeologists are for the most part recruited from the urban middle classes; how many of us are able to live our daily lives without using running tap water, modern plumbing and electricity? Or cook food on a primitive stove? Till a field without modern technology (or till a field at all!) etc. etc.?

In 2006 I went to Iceland and met, among others, young archaeologists from New York. We visited the farmhouses in Pverá, Mývatnssveit, which were abandoned after World War II but leaving everything as it was then. In the kitchen there was an old iron stove, and I could tell the New Yorkers that I knew how to cook on such a stove, how to regulate the heat etc. "Why do you know this?" they asked. I told them about my childhood's traditional Norwegian cottage life without electricity and bathrooms, and later how we often as archaeologists could live for months in primitive mountain dairy farms (Norwegian setre or stølshus) or forest cabins without electricity. They looked at me as if I were an alien.

\section{ARCHAEOLOGY AS ARCHAEOLOGY?}

In this section Olsen presents both his strengthened confidence that a renewed archaeology of things will not just be "an alternative to history" but produce "alternative histories". However, he is also somewhat defeatist, showing a loss of confidence in the ability of the things themselves to contribute to History. Olsen seems to mean that archaeology can only imperfectly contribute to topics like social and political organization, socio-cultural structure, things as symbols in action etc. He does not believe in "middle-range magic", and as far as I understand him, archaeology will be considered "inferior" if our ambitions continue to be too "airy". He maintains that "we work with the messy spoils of history" and that this "otherness" of the archaeological record is not "a problem, representing loss, failure or defect".

What I do not understand in Olsen's line of reasoning is why these spoils are too inferior to contribute to the "History" of humankind. My failure to understand may stem from the fact that Olsen does not define what he means by "History". Leo Klejn's (1993) distinction between the 
fields and goals of archaeology and prehistory comes to mind. However, Olsen does not, as Klejn did, see archaeology as a data-producing method for historians to process. But he requires (pre)history to be kept outside of an archaeology as archaeology. This is a trajectory for archaeology that I, as an archaeologist also working with written sources, for the moment do not find very constructive. But of course I might have missed a "deep" point here.

On the other hand, I'm all ears when Olsen describes the discoveries and thrills of fieldwork; the engagement with a place is "all very different from reading about" it. He exemplifies the thrills of discovery with "a chert blade not seen or touched by other humans for thousands of years...”. Here Olsen exposes an enthusiasm for age! Well, sequencing and chronology are still important...

Concerning the thrills and toils of fieldwork Olsen quotes a passage by Renfrew. I shall be utterly immodest and quote from my doctoral dissertation written in I993:

The physical labour of fieldwork transforms the intellectual quest for knowledge of the past through material culture into a very personal, embodied experience. The physical toil is stored in your body, maybe for the rest of your life, inherent in defunct knees and elbows, and an aching back. On a long-term fieldwork project very "unscientific" ideas come to your mind. The very aspect of "being there", learning to know the physical environment and people living in the landscape, and constantly trying to imagine how it could have been living there then, all these mentally and bodily experiences embrace you totally and drive you into a state of empathy. By living in the same place as the past "others" did, I feel that I can better understand how it was like then. This emotional and physical experience of empathy is maybe non-science, but it sure does not feel like non-sense. This experienced and embodied knowledge is used to make sense literally of the archaeological record. After a time of physical out-door work, the rhythm of day and night, sun, rain and showers, light and mist, and landscapes become part of you. You, the reader, might want to classify this line of thought less as a state of empathy and more like an overwrought state of nature-mysticism. But working on Veøy really felt like a total and emotional experience of body and soul. The theoretical was intrinsically personal and vice versa (Solli I996:30-3I).

Olsen makes a call for archaeology to become more descriptive and the aim should be to "produce rich descriptive accounts that also understand and interpret, not by heading beyond things and the immediate world, or by leaving out what arises in the momentary presence of encounter, but by allowing them a rightful share." 
What does he mean by rich descriptive accounts? Detailed descriptive accounts? Clifford Geertz divided descriptions into "thin" and "thick" (Geertz 1973). He exemplified this by describing a wink. A "thin description" of a wink describes it as a physical phenomenon, but a "thick description" of a wink contextualizes it and seeks to uncover the symbolic meaning behind the wink.

Since Olsen encourages us not to be so obsessed with finding the meaning behind e.g. the petroglyph of a boat but to focus on the material affordances of the boat, that it can be used as a floating and transport device for people, I suppose that by a rich description he does not mean thick description. He emphasizes that archaeologists describing things should "let us be inspired by the descriptive richness the antiquarians aimed at....". The antiquarians of the eighteenth and nineteenth centuries sometimes did not distinguish between cultural and natural phenomena; the descriptions could be anecdotal and cover several disciplines; disciplines which themselves were in the process of becoming, cf. above on Schnitler's discovery. I'm not sure if the antiquarian more or less hybrid way of writing is the path to pursue when doing archaeology as archaeology. However, when Olsen suggests that we should compose more creative and playful descriptions, even telling of thrills of discovery and the life in the field, like adventurers and explorers have done, I entirely agree with him.

\section{CONCLUSION}

Bjørnar Olsen started his excursion pointing to the perhaps not so innovative phenomenon, that we are "haunted by anniversaries". Perhaps the academically most wide-ranging $20 \mathrm{I} 2$ anniversary is the following: Fifty years ago Thomas S. Kuhn published The Structure of Scientific Revolutions (1962). His notions of normal science, puzzle-solving, incommensurability and paradigm shifts are household concepts in any discussion of disciplinary change. Kuhn's object of study was the natural Sciences but the concept of paradigm and paradigm shift are now widely applied both inside and outside Academia. The majority of people applying the concept have never read Kuhn and do not know in what context it was supposed to be employed. I have elsewhere maintained that I do not see archaeology as a paradigmatic science in the Kuhnian sense of the concept; in the humanities and social sciences there are traditions and schools, not paradigms (Solli 1989a:29). Neither the New Archaeology nor postprocessual archaeology represented paradigm shifts in accordance with Kuhn's definition of the concept. Archaeological meth- 
ods developed in the nineteenth and early twentieth century, such as typological analysis, classification, analysis of stratigraphy and excavation techniques, still constitute basic skills in archaeology.

The turn to a "rich description of things", analysing gatherings of things as palimpsests in the present, and toning down the quest for meaning, is in my opinion not a paradigm shift in any Kuhnian sense of the concept. It may represent a praxis breaking with the linguistic and human-centred frame of interpretation, but not a total break. Language and writing (Olsen's "rich description") is nonetheless on the agenda, and human-made things are persistently at the core of archaeology. I do not see the turn to things movement as a return to Montelius or any of the older traditions of doing archaeology; a full U-turn backwards is impossible because of the insights learned from both the New Archaeology and postprocessual archaeology. The turn to things will, as far as I can see, be too enmeshed in traditional archaeological methods to be proclaimed a new paradigm. For example, if an archaeological record is to be profoundly (richly?) described as a palimpsest there has to be, in some form or other, a description of formation processes. However, the perspectives presented by Olsen in this keynote article can constitute an archaeological moment if enough of us critically take up the challenge.

Brit Solli

Museum of Cultural History, University of Oslo/ Centre for Advanced Study, at the Norwegian Academy for Science and Letters Drammensveien 78 027I Oslo Norway

\section{REFERENCES}

Andrén, A. 1985. Den urbana scenen. Malmö: Liber.

Bernstein, R. J. 1983. Beyond objectivism and relativism. Science, hermeneutics, and praxis. Oxford: Basil Blackwell.

Binford, L. R. 1962. Archaeology as Anthropology. American Antiquity. Vol. 28(2). Pp. 217-225.

Binford, L. R. I982. Meaning, Inference and the Material Record. In: Renfrew, C. \& Shennan, S. (Eds). Ranking, Resource and Exchange. Aspects of the Archaeology of Early European Society. Pp. I60-I63. Cambridge: Cambridge University Press.

Borges, J. 1983. Nueva Antología personal. México: Siglo Veintiuno Editores.

Bourdieu, P. 1977. Outline of a Theory of Practice. Cambridge: Cambridge University Press.

Clark, J. G. D. 1936. The Mesolithic Settlement of Northern Europe. Cambridge: Cambridge University Press. 
Clark, J. G. D. 1954. Excavations at Star Carr. Cambridge: Cambridge University Press. Clarke, D. 1973. Archaeology. The Loss of Innocence. Antiquity. Vol. XLVII. Pp. 6-ı8.

Edgeworth, M. 20I2. Follow the Cut, Follow the Rhythm, Follow the Material. With comments from Å. Berggren, A. González-Ruibal, T. Ingold, G. Lucas, R. Skeates, and C. Witmore. Norwegian Archaeological Review. Vol. 45(I). Pp. 76-II 4.

Foucault, M. 1972. The Archaeology of Knowledge. London \& New York: Routledge. Geertz, C. I973. The Interpretation of Cultures. Selected Essays. New York: Basic Books.

Gibson, J. J. 1986. The Ecological Approach to Visual Perception. Hillsdale N. J.: Lawrence Erlbaum.

Herteig, A. I954. Omkring kaupangen på Veøy i Romsdal. Viking XVIII. Pp. 69-88.

Hodder, I. I982a. Theoretical archaeology: A reactionary viewpoint. In: Hodder, I. (Ed.). Symbolic and Structural Archaeology. Pp. I-I6. Cambridge: Cambridge University Press.

Hodder, I. I982b. Symbols in Action. Ethnoarchaeological Studies of Material Culture. Cambridge: Cambridge University Press.

Klejn, L. I993. To Separate a Centaur: On the Relationship of Archaeology and History in Soviet Tradition. Antiquity. Vol. 67(255). Pp. 339-348.

Kuhn, T. I962. The Structure of Scientific Revolutions. Chicago: University of Chicago Press.

Montelius, O. I885. Om tidsbestämning inom bronsåldern med särskildt afseende på Skandinavien. Kungl. Vitterhets Historie och Antiquitets Akademiens Handlingar, del 30 .

Müller, S. I884. Mindre Bidrag til den forhistoriske Archæologis Methode. Aarbøger for Nordisk Oldkyndighed og Historie. Pp. I6I-2I6.

Nordeide, S. W. I989a. Betente spor. META I989/I. Pp. 3 I-46.

Nordeide, S .W. I989b. Latente og manifeste spor. Reply to Anders Andrén. META I989/4. Pp. 37-39.

Olsen, B. 20IO. In Defense of Things. Archaeology and the Ontology of Objects. Lanham, New York, Toronto, Plymouth: AltaMira Press.

Popper, K. R. 1963. Conjectures and Refutations. The Growth of Scientific Knowledge. London: Routledge \& Kegan Paul.

Rorty, R. I989. Contingency, Irony, and Solidarity. Cambridge: Cambridge University Press.

Schnitler, H. P. I768 [1974]. Beskrivelse over Romsdals Fogderie I768 og I789. Molde: Romsdal Sogelag.

Solli, B. I989a. Dyrebein. Problemer og muligheter omkring et arkeologisk kildemateriale. VARIA I8. Oslo.

Solli, B. 1989b. Norske middelalderbyer og bydannelse. Et arkeologisk utsyn. Viking 52. Pp. I33-I 43 .

Solli, B. I992. Idehistoriske retninger innenfor arkeologi I970-I990. Fra test via tegn til tekst. Fornvännen. Vol. 87. Pp. 99-I07.

Solli, B. 1996. Narratives of Veøy. An Investigation into the Poetics and Scientifics of Archaeology. Universitetets Oldsaksamlings Skrifter 19. Oslo.

Solli, B. 20ri. Some Reflections on Heritage and Archaeology in the Anthropocene. Norwegian Archaeological Review. Vol. 44(I). Pp. 40-54.

Svestad, A. 1995. Oldsakenes orden. Om tilkomsten av arkeologi. Oslo: Universitetsforlaget. 